• 研究报告・

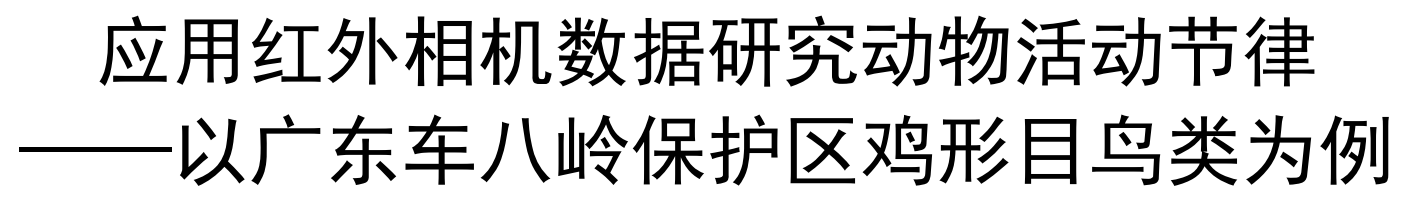

\author{
陈立军 ${ }^{1}$ 束祖飞 ${ }^{3}$ 肖治术 ${ }^{1,2 *}$ \\ 1 (中国科学院动物研究所农业虫害鼠害综合治理研究国家重点实验室, 北京 100101) \\ 2 (中国科学院大学, 北京 100049) \\ 3 (广东车八岭国家级自然保护区, 广东韶关 512500)
}

摘要: 动物活动节律和时间生态位分化是动物行为在时间维度的分布, 是对时间资源利用的重要体现。动物活动 节律受到环境因素和种间作用的影响, 因此, 了解动物活动节律以及时间生态位有助于揭示群落中同域分布物种 时间资源利用的差异及共存机制。近10多年来, 红外相机技术在国内外野生动物监测研究中得到广泛应用, 积累 了大量有时间记录的动物行为数据, 极大地促进了动物活动节律和时间生态位分化的深入研究。本文对动物活动 节律研究以及应用红外相机数据研究动物活动节律的方法进行梳理, 采用核密度估计方法, 利用广东车八岭国家 级自然保护区的红外相机监测数据, 分析了鸡形目鸟类的活动节律, 以阐述单物种和多物种的活动节律以及种间 作用对动物日活动节律的影响。研究结果表明车八岭保护区白閜(Lophura nycthemera)、白眉山麅鸪(Arborophila gingica) 和灰胸竹鸡(Bambusicola thoracica) 等3个鸡形目物种之间存在不同程度的竞争, 物种间的日活动节律呈现 中等程度的重叠。最后, 针对动物活动节律分析方法应用的建议及影响因素进行讨论, 希望为国内动物活动节律 研究提供参考。

关键词: 日活动节律; 红外相机; 鸡形目; 核密度估计; 物种共存; 广东车八岭国家级自然保护区

\title{
Application of camera-trapping data to study daily activity patterns of Galliformes in Guangdong Chebaling National Nature Reserve
}

\author{
Lijun Chen ${ }^{1}$, Zufei Shu ${ }^{3}$, Zhishu Xiao ${ }^{1,2^{*}}$ \\ 1 State Key Laboratory of Integrated Management of Pest Insects and Rodents, Institute of Zoology, Chinese Academy of \\ Sciences, Beijing 100101 \\ 2 University of Chinese Academy of Sciences, Beijing 100049 \\ 3 Guangdong Chebaling National Nature Reserve, Shaoguan, Guangdong 512500
}

\begin{abstract}
Animal activity patterns and temporal niches can indicate the distribution of animal behavior and the utilization resources over time. Environmental variables and interspecific interactions have important effects on animal activity and temporal niche partitioning. These two factors in turn can help understand mechanisms of niche partitioning among sympatric species as well as species coexistence and community composition. Due to the extensive use and deployment of infrared cameras for nearly a decade, a large amount of time-recorded behavioral data has been accumulated. These data are conducive to studying activity rhythms and temporal niches in depth. In the present paper, we reviewed research on animal activity using infrared cameras in combination with in situ monitoring data from the Guangdong Chebaling National Nature Reserve to better understand three Galliformes species. A kernel density was used to estimate the activity and interspecific effects of a single species as well as for multispecies activity. Our study reveals a moderate overlap among Galliformes species, Lophura nycthemera, Arborophila gingica and Bambusicola thoracica, which may be caused by interspecific competition. We discuss the limitations of daily activity analyses to
\end{abstract}

收稿日期: 2018-06-26; 接受日期: 2018-10-26

基金项目: 国家重点研发项目(2017YFC0503802; 2016YFC0500105)、中国科学院生物多样性监测与研究网络兽类多样性监测网运行经费、中国博士 后科学基金(2017M620905)、2017 年中央林业改革发展资金和 2016 年中央财政林业补助资金

* 通讯作者 Author for correspondence. E-mail: xiaozs@ioz.ac.cn 
give a reference for similar research.

Key words: daily activity pattern; infrared camera; Galliformes; kernel density estimation; species coexistence; Guangdong Chebaling National Nature Reserve

近10多年来, 红外相机技术在国内外野生动物 监测研究中得到广泛应用, 积累了大量有时间记录 的野生动物行为数据, 极大地促进了野生动物的活 动节律和时间生态位分化的深入研究(O'Connell et al, 2011; 肖治术等, 2014; Steenweg et al, 2017)。因 此, 了解和掌握动物活动节律的分析方法将有助于 揭示群落中同域分布物种在时间、空间的利用差异 及其共存机制(Ridout \& Linkie, 2009; Rowcliffe et al, 2014; Dominoni et al, 2017)。

目前, 国外应用红外相机数据开展动物活动节 律的研究多以核密度估计方法 (kernel density estimation)分析为主, 用于描述单物种和多物种的 活动节律以及重叠程度 (Ridout \& Linkie, 2009; Oliveira-Santos et al, 2013; Rowcliffe et al, 2014), 主 要类群包括陆生哺乳动物和地栖性鸟类等(Bridges \& Noss, 2011)。陆生哺乳动物主要包括食肉类(Di Bitetti et al, 2010; Monterroso et al, 2014)、有蹄类 (Ferreguetti et al, 2015)、啮齿类(Meek et al, 2012)和 灵长类(Gerber et al, 2012), 鸟类以鸡形目为主( $\mathrm{Li}$ et al, 2010)。采用红外相机数据分析动物活动节律的 研究已经证实同域分布物种的时间生态位分化是 物种稳定共存的主要机制之一(Ridout \& Linkie, 2009; Di Bitetti et al, 2010; Monterroso et al, 2014; Sunarto et al, 2015)。例如, 同域分布的美洲豹 (Panthera onca)和美洲狮(Puma concolor)等6种猫科 动物具有不同的活动节律, 形态相似的长尾虎猫 (Leopardus wiedii)和美洲山猫(Puma yagouaroundi) 分别为夜行性和昼行性, 其他物种为晨昏性, 活动 高峰时间因物种体重不同而不同(Di Bitetti et al, 2009)。

国内早期使用红外相机研究动物日活动节律 的研究对象为刺鼠(Niviventer coxingi)(Pei, 1995)、 猕猴(Macaca mulatta)、鼠獾(Melogale moschata)和 蓝腹㭤(Lophura swinhoii)(裴家骐, 1998)。到21世纪 前10年, 研究的动物类群和种类逐渐增加, 包括小 灵猫(Viverricula indica)、花面狸(Paguma larvata)、 食蟹獴(Herpestes urva) 和鼠獾(Chen et al, 2009)、扭 角羚(Budorcas taxicolor, 李明富等, 2011)以及血雉
(Ithaginis cruentus)和红腹角雉(Tragopan temminckii) 等鸡形目鸟类(Li et al, 2010)。近5年来, 红外相机技 术在我国各级自然保护区的野生动物多样性监测 研究中得到广泛应用(Li et al, 2010; 李晟等, 2014; 肖治术等, 2014, 2017)。应用红外相机研究日活动节 律的动物种类在迅速增加(附录1), 如哺乳动物中的 帚尾豪猪(Atherurus macrourus, 温立嘉等, 2016)、 马鹿(Cervus elaphus, 陈琛等, 2017)、蒙新河狸 (Caster fiber birulai, 刘冬志等, 2015)、普氏野马 (Equus przewalskii, 吴兵等, 2017)、亚洲狗獾(Meles leucurus)、猪獾(Arctonyx collaris)、豹猫(Prionailurus bengalensis)、貉(Nyctereutes procyonoides)、中华斑 羚(Naemorhedus griseus)和野猪(Sus scrofa)(贾晓东 等, 2014; 王长平等, 2015; 张源笙等, 2017), 鸡形 目包括红腹锦鸡(Chrysolophus pictus, 刘小斌等, 2017)、白冠长尾雉(Syrmaticus reevesii, 赵玉泽等, 2013)和白注乌(Lophura nycthemera, 余建平等, 2017) 等。尽管国内基于红外相机数据开展动物活动节律 研究的类群在逐渐增多, 但大多数研究是对各类群 动物活动节律的描述性分析, 而通过活动节律来探 讨群落内物种共存的作用机制的研究仍相对较少 (Li et al, 2010; Bu et al, 2016)。

本文以广东车八岭国家级自然保护区(以下简 称车八岭保护区) 白淮、白眉山麅鸪 (Arborophila gingica)和灰胸竹鸡(Bambusicola thoracica)为研究 对象, 采用核密度估计方法, 比较分析3种竞争物 种之间的活动节律及其重叠程度, 以阐述单物种和 多物种的活动节律以及种间作用对物种活动节律 的影响。

\section{材料与方法}

\section{1 研究地点及数据采集}

车八岭保护区位于广东省始兴县东南部, 总面 积75.45 $\mathrm{km}^{2}$ 。植物区系为南亚热带向中亚热带过渡 类型, 是南岭山脉南缘保存完整、面积较大、分布 集中、原生性较强的具有代表性的中亚热带常绿榈 叶林(徐燕千, 1993)。

我们于2016年底在全区范围布设红外相机对 
区内野生动物进行监测。相机布设方案：以整个保 护区为单位制作 $1 \mathrm{~km} \times 1 \mathrm{~km}$ 网格地图, 采用系统抽 样对车八岭保护区所有网格(80个)进行调查, 即每 个网格设置 1 个相机位点(即 1 台红外相机, 型号为 Ltl-6511), 对陆生大中型兽类和雉鸡类进行为期1 年的物种编目调查, 时间为2016年12月底至2018年 1月初, 每隔3-5个月采集1批数据(共3批数据), 更 换电池和SD卡。所采集的红外相机数据和相机位点 信息上传到图像数据管理系统CameraData, 对所有 采集图像数据进行物种识别和相关数据信息的挖 掘, 最后由系统直接导出Excel数据表进行分析。

\section{2 数据分析原理及方法}

\subsection{1 数据分析原理}

日活动节律的数据类型是以 $24 \mathrm{~h}$ 为周期的数据, 对于该类数据的分析主要采用非参数核密度估计 方法，假设动物行为以 $24 \mathrm{~h}$ 为周期循环的连续时间 分布, 其行为事件是在连续时间分布中进行随机取 样, 核密度估计方法对数据分布不附加任何假定, 是一种从数据样本本身出发研究数据分布特征的 方法(Ridout \& Linkie, 2009)。该方法可计算动物平 均活动时长、中位数、标准差、方差和密度等日活 动节律的主要参数(Lund \& Agostinelli, 2007)。该方 法对多峰的活动数据处理有一定的局限性, 不能准 确预测活动时长和活动高峰等参数(Di Bitetti et al, 2010; Norris et al, 2010; Ramesh et al, 2012)。 Oliveira-Santos等(2013)提出了条件循环核密度方 法计算红外相机数据的活动时长和活动高峰期等 参数, 通过绘制不同的等值线来表征不同活动集中 程度，95\%的等值线表征95\%的活动事件发生的时 间区间，利用 $50 \%$ 的等值线表征日活动高峰。

对于多物种活动节律的重叠分析主要基于核 密度估计的方法, 比较成对物种的日活动节律的重 叠系数。重叠系数是通过最少 2 个周期长度的密度 函数的各时间点上的两两比较而获得 (Ridout \& Linkie, 2009)。Schmid和Schmidt (2006) 关于非参数 估计的重叠系数 $(\Delta)$ 作了详细的研究, 用等价数学 表达式计算重叠系数的 5 个预测值。根据Ridout和 Linkie (2009)以及Meredith和Ridout (2014)的模拟结 果, 重叠系数 $(\Delta)$ 预测值由成对物种中较小的样本 数决定, 如果较小的样本数少于 50 个记录, $\Delta_{1}$ 预测 值最好; 而当较小样本数大于 75 时, $\Delta_{4}$ 预测值表现 最好。

\subsection{2 数据分析方法}

基于核密度估计方法分析红外相机数据的动 物日活动节律, 主要涉及 R软件的 overlap包(Meredith \& Ridout, 2014)和activity包(Rowcliffe, 2016)。 具体的数据分析步骤包括前期的图像数据鉴定与 预处理以及基于 $\mathrm{R}$ 软件进行日活动节律数据分析 2 个主要步骤:

(1)图像数据鉴定与预处理。每个物种所拍摄照 片数不能直接用于动物活动节律分析, 首先需要计 算独立有效照片数(O’Brien et al, 2003)。本研究设定 同一位点30 min内拍到的同种多张照片或视频，记 为1张独立有效照片。

(2)基于 $R$ 软件进行日活动节律数据分析的具体 分析流程如下:

(a)将独立有效照片的时间转化为弧度数据，首 先由原始时间数据(时: 分: 秒)转为小数(数值范围 $0-1)$, 再转化为弧度数据。

(b) 导入 overlap包，用densityPlot()函数绘制单 物种核密度曲线图, 曲线的平滑度由densityPlot函 数的adjust参数调整(adjust $\geq 1$ 时为默认值, 绘制平 滑曲线; adjust $<1$ 时, 绘制螺旋曲线), 调整adjust参 数会影响活动节律重叠度的计算结果。根据Ridout 和Linkie (2009)模拟结果, 建议用adjust $=0.8$ 计算 $\Delta_{1}$, adjust $=1$ 计算 $\Delta_{4}$ 。

(c)用overlapEst()函数计算重叠系数。根据成对 物种较小的样本数, 选取合适的重叠系数, 判断重 叠程度。

(d)平滑自主抽样(smoothed bootstrap), 核密度 曲线拟合原始观察值, 然后随机取样模拟观察值, 采用平滑自主抽样计算重叠系数的置信区间。

(e)活动节律的重叠度是纯描述性的，没有提供 一个阈值验证物种的活动节律差异是否显著。 activity包的compareCkern()函数利用Wald test对同 一分布的循环预测值进行概率检验 (Rowcliffe, 2016)。

本研究的数据及 $\mathrm{R}$ 代码见附录 2 和附录 3 。

\section{2 结果}

2017年调查期间共获得白㭤、灰胸竹鸡、白眉 山麅鸪 3 种鸟类的独立有效照片 2,983 张，其中白闲 2,658 张, 白眉山麅鸪 200 张, 灰胸竹鸡 125 张。活动 
节律分析表明: 白㜀为昼行性, 活动高峰在 8:0015:00; 白眉山椨鸪为昼行性, 在 8:00和 17:00出现2 个活动高峰; 灰胸竹鸡亦为昼行性, 在 9:00和18:00 出现2个活动高峰(图1)。

三种鸡形目鸟类的日活动节律重叠程度的分 析结果表明, 白鹂与白眉山鹤鸪活动节律的重叠系 数为 0.80 , 日活动节律曲线差异显著 $(\Delta=0.80, P<$ 0.01 ); 白酠与灰胸竹鸡活动节律的重叠系数为 0.86 , 日活动节律曲线差异显著 $(\Delta=0.86, P=0.02)$; 灰胸 竹鸡与白眉山椨鸪活动节律的重叠系数为 0.87 , 日 活动节律曲线差异不显著 $(\Delta=0.87, P=0.14$ ) (图1)。 以上结果表明白鹇作为优势种与灰胸竹鸡和白眉 山嗻鸪等具有明显的日活动节律分化, 而灰胸竹鸡 和白眉山麅鸪的活动节律无显著分化。
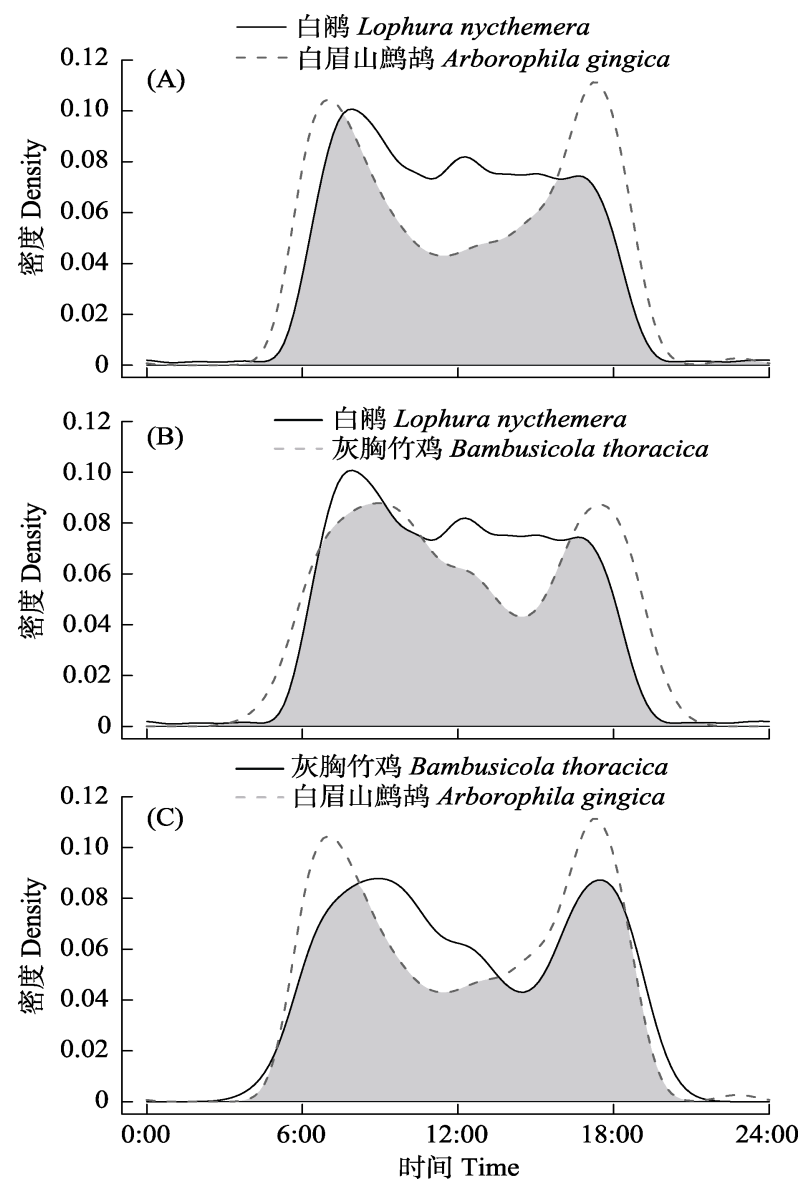

图1 车八岭国家级自然保护区白酠和白眉山麅鸪(A)、白㼛 和灰胸竹鸡 (B)、白眉山鹤鸪和灰胸竹鸡 $(C)$ 的活动节律曲线 比较, 灰色为重叠区域。

Fig. 1 Comparison of daily activity patterns of Lophura nycthemera, Arborophila gingica and Bambusicola thoracica, in Chebaling National Nature Reserve. The overlapping coefficient equals the area in grey.

\section{3 讨论}

本研究以车八岭保护区的3种鸡形目鸟类为研 究对象, 采用核密度估计方法对3种鸟类的日活动 节律及其重叠程度进行了分析, 发现车八岭保护区 中白洞鸟、白眉山麅鸪和灰胸竹鸡等 3 个鸡形目物种 之间存在不同程度的竞争, 物种间活动节律呈现为 中等程度的重叠。同时本研究对动物日活动节律及 其重叠程度的数据分析相关的 $\mathrm{R}$ 语言软件包进行了 详细介绍, 为国内动物活动节律研究提供参考。

活动节律分析的结果还受其他因素的影响。动 物日活动节律受本地昼夜时长的影响, 日出和日落 时间的变化导致物种活动高峰提前或延迟, 尤其是 在高纬度地区, 昼夜长度和日出日落时间存在明显 的季节性变化, 不同季节对同种动物调查结果可能 截然不同, 因此, 不同纬度地区的比较研究中, 日 出日落时间的动态对动物活动节律的影响不容忽 视(Aschoff, 1966; Nouvellet et al, 2012)。此外动物活 动节律的比较研究也最好是在同一纬度和相同季 节的不同区域间进行。本研究中采用同一研究地点 的鸡形目鸟类的活动数据, 因此, 不用考虑地区日 出日落时间差异的影响, 但本研究采用的数据集为 保护区全年的监测数据, 可能存在日出日落时间季 节性差异的影响, 在进一步的研究中应考虑不同季 节的鸡形目鸟类活动节律的差异比较。群落内物种 的日活动节律及其重叠程度同时受到环境梯度及 人类干扰的影响, 环境因素和人为干扰导致活动重 叠变化的规律和机制有待进一步研究。

动物活动节律受到实验设计及相机布设方案 的影响。目前应用于活动节律分析的数据多来源于 以生物多样性监测研究为主的实验设计。此类研究 的相机布设方案与以活动节律研究为主的相机布 设方案有所不同, 后者需要更多地考虑研究对象 的活动范围与相机的间隔距离, 不同的相机间距 适用于不同的动物类群的活动节律研究( $\mathrm{O}^{\prime}$ Connell et al, 2011)。以生物多样性监测调查为目的的相机 布设以固定距离监测所有动物类群, 不能满足“特 定时间段内动物被红外相机记录到的概率与其本 身活动强度成正相关” 的前提假设, 应用该类数据 分析动物活动节律时可能会出现偏差(Rowcliffe et al, 2014)。在动物活动节律研究的相机布设方案中, 相机间距一般不超过物种家域的直径距离 
(Rowcliffe et al, 2014)。此外, 红外相机方法并不适 合于所有动物类群, 仅适用于地面活动为主的动物 类群(O’Connell et al, 2011)。

在动物活动节律及其生态和进化机制研究中, 红外相机技术应与其他调查方法紧密结合，综合多 种技术优势(Frey et al, 2017)。近年来, 研究人员开 始将红外相机、遥测方法和直接观察方法结合起 来。Leuchtenberger等(2013)在对大水獭(Pteronura brasiliensis)的行为节律研究中, 将红外相机布设在 兽穴口附近和排泄点, 记录其全天兽穴的利用和气 味标记行为; 此外, 在白天还采用遥测和直接观察 (目标取样法)两种方法研究水獭群的行为。Suselbeek等(2014)综合自动遥测系统、手动遥测和红外 相机三种方法, 以新热带雨林的中美毛臀刺鼠 (Dasyprocta punctate)和虎猫(Leopardus pardalis)为 研究对象，验证避让捕食风险假说(risk allocation hypothesis)。综合多种方法的研究具有明显的技术 优势, 获得的行为数据更加全面完整, 但不同方法 获得的行为学数据的整合成为目前急需解决的问 题。此外, 动物活动节律和时间生态位与空间生态 位的研究结合, 可从时空生态位立体研究物种对环 境变化的响应, 以便全面理解种间互作和群落动态 过程, 为拓展生态学理论和动物保护决策制定提供 科学基础。

利用红外相机技术收集动物的行为及其活动 节律数据, 有利于全面掌握动物日活动节律以及物 种间的相互作用和群落构建的机制。虽然目前关于 动物活动节律的研究以及分析方法有了很大进步, 但仍有许多问题值得探索。首先, 环境因素对活动 节律影响的分析方法还不够完善, 较多的研究集中 在单个环境因素对活动节律的影响, 而考虑多个环 境因素对活动节律影响的研究还较少。其次, 较少 有研究评估不同实验设计采集的数据对动物活动 节律研究结果的影响; 最后, 人类干扰对野生动物 的影响受到极大关注, 导致人类干扰对动物活动节 律的影响也成为物种保护研究的重要内容之一。因 此, 今后的研究应加强探讨多个环境因素以及人为 干扰对动物活动节律和时间生态位分化影响的研 究, 这有助于理解物种共存机制以及物种保护政策 的制定。
致谢: 感谢广东车入岭国家级自然保护区管理人员 以及野外调查人员的支持。

\section{参考文献}

Aschoff J (1966) Circadian activity pattern with two peaks. Ecology, 47, 657-662.

Bridges AS, Noss AJ (2011) Behavior and activity patterns. In: Camera Traps in Animal Ecology (eds O'Connell AF, Nichols JD, Karanth KU), pp. 57-69. Springer, Tokyo.

Bu H, Wang F, McShea WJ, Lu Z, Wang D, Li S (2016) Spatial co-occurrence and activity patterns of mesocarnivores in the temperate forests of Southwest China. PLoS ONE, 11, e0164271.

Chen C, Hu L, Chen ZJ, Jiang XL, Wu LJ, Wang XL, Bao WD (2017) Variations in seasonal activity pattern of red deer in southern part of Daxing'an Ling Mountains, northeastern China. Journal of Beijing Forestry University, 39(4), 55-62. (in Chinese with English abstract) [陈琛, 胡否, 陈照娟, 姜秀丽, 乌力吉, 王晓玲, 鲍伟东 (2017) 大兴安岭南段 马鹿日活动节律的季节变化研究. 北京林业大学学报, 39(4), 55-62.]

Chen MT, Tewes ME, Pei KJ, Grassman LI (2009) Activity patterns and habitat use of sympatric small carnivores in southern Taiwan. Mammalia, 73, 20-26.

Di Bitetti MS, De Angelo CD, Di Blanco YE, Paviolo A (2010) Niche partitioning and species coexistence in a neotropical felid assemblage. Acta Oecologica, 36, 403-412.

Di Bitetti MS, Di Blanco YE, Pereira JA, Paviolo A, Pírez IJ (2009) Time partitioning favors the coexistence of sympatric crab-eating foxes (Cerdocyon thous) and pampas foxes (Lycalopex gymnocercus). Journal of Mammalogy, 90, 479-490.

Dominoni DM, Åkesson S, Klaassen R, Spoelstra K, Bulla M (2017) Methods in field chronobiology. Philosophical Transactions of the Royal Society B: Biological Sciences, 372, 20160247.

Ferreguetti ÁC, Tomás WM, Bergallo HG (2015) Density, occupancy, and activity pattern of two sympatric deer (Mazama) in the Atlantic forest, Brazil. Journal of Mammalogy, 96, 1245-1254.

Frey S, Fisher JT, Burton AC, Volpe JP, Rowcliffe M (2017) Investigating animal activity patterns and temporal niche partitioning using camera-trap data: Challenges and opportunities. Remote Sensing in Ecology and Conservation, 3, 123-132.

Gerber BD, Karpanty SM, Randrianantenaina J (2012) Activity patterns of carnivores in the rain forests of Madagascar: Implications for species coexistence. Journal of Mammalogy, 93, 667-676.

Jia XD, Liu XH, Yang XZ, Wu PF, Songer M, Cai Q, He XB, Zhu Y (2014) Seasonal activity patterns of ungulates in Qinling Mountains based on camera-trap data. Biodiversity 
Science, 22, 737-745. (in Chinese with English abstract) [贾 晓东, 刘雪华, 杨兴中, 武鹏峰, Songer M, 蔡琼, 何祥 博, 朱云 (2014) 利用红外相机技术分析秦岭有蹄类动 物活动节律的季节性差异. 生物多样性, 22, 737-745.]

Leuchtenberger C, Zucco CA, Ribas C, Magnusson W, Mourão G (2013) Activity patterns of giant otters recorded by telemetry and camera traps. Ethology Ecology \& Evolution, 26, 19-28.

Li MF, Li S, Wang DJ, McShea WJ, Guan TP, Chen LM (2011) The daily activity patterns of takin Budorcas taxicolor in winter and spring at Tangjiahe Nature Reserve, Sichuan Province. Sichuan Journal of Zoology, 30, 850-855. (in Chinese with English abstract) [李明富, 李晟, 王大军, McShea WJ, 官天培, 谌利民 (2011) 四川唐家河自然保 护区扭角羚冬春季日活动模式研究. 四川动物, 30, 850-855.]

Li S, McShea WJ, Wang DJ, Shao LK, Shi XG (2010) The use of infrared-triggered cameras for surveying phasianids in Sichuan Province, China. Ibis, 152, 299-309.

Li S, Wang DJ, Xiao ZS, Li XH, Wang TM, Feng LM, Wang $\mathrm{Y}$ (2014) Camera-trapping in wildlife research and conservation in China: Review and outlook. Biodiversity Science, 22, 685-695. (in Chinese with English abstract) [李晟, 王 大军, 肖治术, 李欣海, 王天明, 冯利民, 王云 (2014) 红外相机技术在我国野生动物研究与保护中的应用与前 景. 生物多样性, 22, 685-695.]

Liu DZ, Huang XW, Chu HJ, Liu YC, Zhang F, Chen G, Qi YJ (2015) Activity rhythms of Sino-Mongolia beaver (Caster fiber birulai) measured with infrared camera traps in Xinjiang, China. Arid Zone Research, 32, 205-211. (in Chinese with English abstract) [刘冬志, 黄效文, 初红军, 刘元超, 张帆, 陈刚, 戚英杰 (2015) 基于红外相机陷阱技术的蒙 新河狸(Caster fiber birulai)活动节律. 干旱区研究, 32, 205-211.]

Liu XB, Wei W, Zheng XG, Zhao KH, He SW, Zhou WL (2017) Activity rhythms of golden pheasant (Chrysolophus pictus) and satyr tragopan (Tragopan temmminckii) revealed by infrared-triggered cameras. Chinese Journal of Zoology, 52, 194-202. (in Chinese with English abstract) [刘小斌, 韦伟, 郑篵光, 赵凯辉, 何少文, 周文良 (2017) 红腹锦 鸡和红腹角雉活动节律一一基于红外相机监测数据. 动 物学杂志, 52, 194-202.]

Liu XH, Wu PF, Songer M, Cai Q, He XB, Zhu Y, Shao XM (2013) Monitoring wildlife abundance and diversity with infrared camera traps in Guanyinshan Nature Reserve of Shaanxi Province, China. Ecological Indicators, 33, 121-128.

Lund U, Agostinelli C (2007) Circstats: Circular statistics. https://CRAN.R-project.org/package $=$ CircStats. (accessed on 2019-01-07)

Meek PD, Zewe F, Falzon G (2012) Temporal activity patterns of the swamp rat (Rattus lutreolus) and other rodents in north-eastern New South Wales, Australia. Australian Mammalogy, 34, 223-233.
Meredith M, Ridout M (2014) Overlap: Estimates of coefficient of overlapping for animal activity patterns. https://CRAN.Rproject.org/package=overlap. (accessed on 2019-01-07)

Monterroso P, Alves PC, Ferreras P (2014) Plasticity in circadian activity patterns of mesocarnivores in Southwestern Europe: Implications for species coexistence. Behavioral Ecology and Sociobiology, 68, 1403-1417.

Norris D, Michalski F, Peres CA (2010) Habitat patch size modulates terrestrial mammal activity patterns in Amazonian forest fragments. Journal of Mammalogy, 91, 551-560.

Nouvellet P, Rasmussen GSA, Macdonald DW, Courchamp F, Braae A (2012) Noisy clocks and silent sunrises: Measurement methods of daily activity pattern. Journal of Zoology, 286, 179-184.

O’Brien TG, Kinnaird MF, Wibisono HT (2003) Crouching tigers, hidden prey: Sumatran tiger and prey populations in a tropical forest landscape. Animal Conservation, 6, 131-139.

O’Connell AF, Nichols JD, Karanth KU (2011) Camera Traps in Animal Ecology: Methods and Analyses. Springer, New York.

Oliveira-Santos LGR, Zucco CA, Agostinelli C (2013) Using conditional circular kernel density functions to test hypotheses on animal circadian activity. Animal Behaviour, 85, 269-280.

Pei KJ (1995) Activity rhythm of the spinous country rat (Niviventer coxingi) in Taiwan. Zoological Studies, 34, 55-58.

Pei KJ (1998) An evaluation of using auto-trigger cameras to record activity patterns of wild animals. Taiwan Journal of Forestry Science, 13, 317-324. (in Chinese with English abstract) [裴家骐 (1998) 利用自动照相设备记录野生动 物活动模式之评估. 台湾林业科学, 13, 317-324.]

Ramesh T, Kalle R, Sankar K, Qureshi Q, Bennett N (2012) Spatio-temporal partitioning among large carnivores in relation to major prey species in Western Ghats. Journal of Zoology, 287, 269-275.

Ridout MS, Linkie M (2009) Estimating overlap of daily activity patterns from camera trap data. Journal of Agricultural, Biological and Environmental Statistics, 14, 322-337.

Rowcliffe JM, Kays R, Kranstauber B, Carbone C, Jansen PA, Fisher D (2014) Quantifying levels of animal activity using camera trap data. Methods in Ecology and Evolution, 5, 1170-1179.

Rowcliffe M (2016) Activity: Animal Activity Statistics. https://CRAN.R-project.org/package=activity. (accessed on 2019-01-07)

Schmid F, Schmidt R (2006) Multivariate extensions of Spearman's rho and related statistics. Statistics and Probability Letters, 77, 407-416.

Steenweg R, Hebblewhite M, Kays R, Ahumada RJ, Fisher JT, Burton C, Townsend SE, Carbone C, Rowcliffe JM, Whittington J, Brodie J, Royle JA, Switalski A, Clevenger AP, Heim N, Rich LN (2017) Scaling-up camera traps: 
Monitoring the planet's biodiversity with networks of remote sensors. Frontiers in Ecology and the Environment, 15, 26-34.

Sunarto S, Kelly MJ, Parakkasi K, Hutajulu MB (2015) Cat coexistence in central Sumatra: Ecological characteristics, spatial and temporal overlap, and implications for management. Journal of Zoology, 296, 104-115.

Suselbeek L, Emsens WJ, Hirsch BT, Kays R, Rowcliffe JM, Zamora-Gutierrez V, Jansen PA (2014) Food acquisition and predator avoidance in a Neotropical rodent. Animal Behaviour, 88, 41-48.

Wang CP, Liu XH, Wu PF, Cai Q, Shao XM, Zhu Y, Songer M (2015) Research on behavior and abundance of wild boar (Sus scrofa) via infrared camera in Guanyinshan Nature Reserve in Qinling Mountains, China. Acta Theriologica Sinica, 35, 147-156. (in Chinese with English abstract) [王 长平, 刘雪华, 武鹏峰, 蔡琼, 邵小明, 朱云, Songer M (2015) 应用红外相机技术研究秦岭观音山自然保护区内 野猪的行为和丰富度. 兽类学报, 35, 147-156.]

Wen LJ, Guo YM, Huang J, Song Y (2016) The activity rhythm of the Asiatic brush-tailed porcupine Atherurus macrourus and its correlation with the phases of the moon. Chinese Journal of Zoology, 51, 347-352. (in Chinese with English abstract) [温立嘉, 郭玉民, 黄建, 宋阳 (2016) 帚 尾豪猪活动节律及其与月光周期的相关性. 动物学杂志, 51, 347-352.]

Wu B, Chu WW, Wu HP, Ren SB, He L, Ge Y, Bu L, Chu HJ (2017) Activity rhythms of reintroducing Przewalski's horse (Equus przewalskii) at watering holes by camera traps. Chinese Journal of Zoology, 52, 545-554. (in Chinese with English abstract) [吴兵, 初雯雯, 吴洪潘, 任松柏, 贺雷, 葛炎, 布兰, 初红军 (2017) 卡拉麦里山有蹄类自然保护 区水源地野放普氏野马的活动节律: 基于红外相机监测 数据. 动物学杂志, 52, 545-554.]

Xiao ZS, Li XH, Jiang GS (2014) Applications of camera trapping to wildlife surveys in China. Biodiversity Science, 22, 683-684. (in Chinese) [肖治术, 李欣海, 姜广顺 (2014) 红外相机技术在我国野生动物监测研究中的应 用. 生物多样性, 22, 683-684.]
Xiao ZS, Li XY, Xiang ZF, Li M, Jiang XL, Zhang LB (2017) Overview of the mammal diversity observation network of Sino BON. Biodiversity Science, 25, 237-245. (in Chinese with English abstract) [肖治术, 李学友, 向左甫, 李明, 蒋 学龙, 张礼标 (2017) 中国兽类多样性监测网的建设规 划与进展. 生物多样性, 25, 237-245.]

Xu YQ (1993) A comprehensive report on investigation in Chebaling National Nature Reserve. In: Collected Papers for Investigation in Chebaling National Nature Reserve (ed. Editorial Committee of Collected Papers for Investigation in Chebaling National Nature Reserve), pp. 1-7. Guangdong Science and Technology Press, Guangzhou. (in Chinese with English abstract) [徐燕千 (1993) 车八岭国家级自然 保护区调查研究综合报告. 见: 车八岭国家级自然保护 区调查研究论文集 (车八岭国家级自然保护区调查研究 论文集编委会编), 1-7页. 广东科技出版社，广州.]

Yu JP, Qian HY, Chen XN, Li S, Shen XL (2017) Daily activity pattern of silver pheasant (Lophura nycthemera) using camera-traps. Chinese Journal of Zoology, 52, 937-944. (in Chinese with English abstract) [余建平, 钱海 源, 陈小南, 李晟, 申小莉 (2017) 基于红外相机技术的 白闲鸟活动节律研究. 动物学杂志, 52, 937-944.]

Zhang YS, Jiang J, Jiang WJ, Wang D, Fan YQ, Tang XM, Bao WD (2017) Activity patterns of mammals in Beijing Songshan National Nature Reserve. Sichuan Journal of Zoology, 36, 460-467. (in Chinese with English abstract) [张源笙, 蒋健, 蒋万杰, 王丹, 范雅倩, 汤小明, 鲍伟东 (2017) 北京松山国家级自然保护区兽类活动节律初步研 究. 四川动物, 36, 460-467.]

Zhao YZ, Wang ZC, Xu JL, Luo X, An LD (2013) Activity rhythm and behavioral time budgets of wild Reeves's pheasant (Syrmaticus reevesii) using infrared camera. Acta Ecologica Sinica, 33, 6021-6027. (in Chinese with English abstract) [赵玉泽, 王志臣, 徐基良, 罗旭, 安丽丹 (2013) 利用红外照相技术分析野生白冠长尾雉活动节律及时间 分配. 生态学报, 33, 6021-6027.]

(责任编委: 丁 平 责任编辑: 问文杰)

\section{附录 Supplementary Material}

\section{附录1 国内基于红外相机数据研究动物活动节律的文献(截至2018年6月)}

Appendix 1 The research papers of animal activity pattern using infrared camera in China (before June 2018) http://www.biodiversity-science.net/fileup/PDF/2018178-1.pdf

\section{附录2 广东车八岭国家级自然保护区3种鸡形目鸟类活动节律数据}

Appendix 2 The activity data of three Galliformes species in Guandong Chebaling National Nature Reserve http://www.biodiversity-science.net/fileup/PDF/2018178-2.xlsx 
陈立军, 束祖飞, 肖治术. 应用红外相机数据研究动物活动节律一一以广东车八岭保护区鸡形目鸟类为例. 生物多样性, 2019, 27 (3): $266-272$.

http://www.biodiversity-science.net/CN/10.17520/biods.2018178

附录1 国内基于红外相机数据研究动物活动节律的文献(截至2018年6月)

Appendix 1 The research papers of animal activity pattern using infrared camera in China (before June 2018)

\begin{tabular}{|c|c|c|c|}
\hline 物种 Species & 研究地点 Research sites & 科学问题 Scientific objectives & 参考文献 References \\
\hline 刺鼠(Niviventer coxingi) & 台湾 & 日活动节律 & Pei, 1995 \\
\hline 猕猴(Macaca mulatta)、鼠獾(Melogale moschata)、蓝腹誠(Lophura swinhoii) & 台湾 & 活动节律的研究方法评估 & 裴家骐, 1998 \\
\hline 小鹿(Muntiacus reevesi) & 台湾 & 日活动节律 & McCullough et al, 2000 \\
\hline 黑熊(Ursus thibetanus) & 台湾 & 日活动节律以及季节性变化 & Hwang \& Garshelis, 2007 \\
\hline $\begin{array}{l}\text { 小灵猫(Viverricula indica)、花面狸(Paguma larvata)、食蟹獴(Herpestes urva)、鼠獾 } \\
\text { (Melogale moschata) }\end{array}$ & 台湾 & 活动节律和生境利用 & Chen et al, 2009 \\
\hline 血雉(Ithaginis cruentus)、红腹角雉(Tragopan temminckii) & 四川王朗和卧龙国家级自然保护区 & 日活动节律 & Li et al, 2010 \\
\hline 扭角羚(Budorcas taxicolor) & 四川唐家河 & 日活动节律 & 李明富等, 2011 \\
\hline 黑鹿(Muntiacus crinifron) & 浙江古田山国家级自然保护区 & 日活动节律以及季节性变化 & 章书声等, 2012 \\
\hline 白冠长尾雉(Syrmaticus reevesii) & 湖北省广水市蔡河 & 日活动节律以及季节性变化 & 赵玉泽等, 2013 \\
\hline 狼(Canis lupus) & 新疆卡拉麦里山有蹄类自然保护区 & 日活动节律 & 王波等, 2014 \\
\hline 野骆驼(Camelus ferus) & 甘肃敦煌西湖国家级自然保护区 & 日活动节律 & 薛亚东等, 2015 \\
\hline 大熊猫(Ailuropoda melanoleuca)、毛冠鹿(Elaphodus cephalophus) & 四川王朗国家级自然保护区 & 日活动节律与节律重叠 & 段利娟, 2014 \\
\hline 亚洲狗獾(Meles leucurus) & 青海湖地区 & 日活动节律 & 李峰和蒋志刚, 2014 \\
\hline 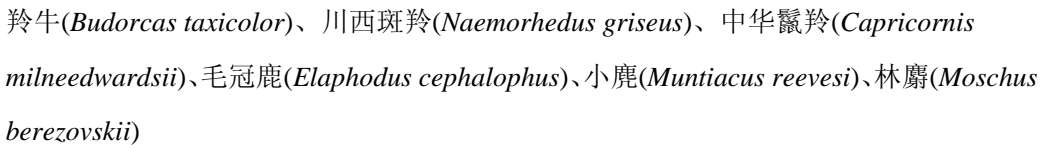 & 陕西观音山自然保护区 & 日活动节律以及季节性变化 & 贾晓东等, 2014 \\
\hline 蒙新河狸(Caster fiber birulai) & 新疆布尔根河狸自然保护区 & 活动模式 & 刘冬志等, 2015 \\
\hline 梅花鹿(Cervus nippon) & 吉林珲春国家级自然保护区 & 日活动节律以及季节性变化 & 黄沛琳等, 2015 \\
\hline 赤麀(Muntiacus muntjak) & 广西弄岗国家级自然保护区 & 日活动节律以及季节性变化 & 汪国海等, 2015 \\
\hline 梅花鹿(Cervus nippon)、野猪(Sus scrofa)、马鹿(Cervus elaphus)、狍(Capreolus pygargus) & 吉林汪清国家级自然保护区 & 日活动节律以及季节性变化 & 李琦, 2015 \\
\hline 野猪(Sus scrofa) & 秦岭观音山自然保护区 & 日活动节律以及季节性变化 & 王长平等, 2015 \\
\hline
\end{tabular}


陈立军, 束祖飞, 肖治术. 应用红外相机数据研究动物活动节律一一以广东车八岭保护区鸡形目鸟类为例. 生物多样性, 2019, 27 (3): $266-272$. http://www.biodiversity-science.net/CN/10.17520/biods.2018178

\begin{tabular}{|c|c|c|c|}
\hline 花面狸(Paguma larvata)、豹猫(Prionailurus bengalensis)、猪獾(Arctonyx collaris)、黄喉 & 四川戉山北部 & 物种共存和活动节律重叠 & Bu et al, 2016 \\
\hline \multicolumn{4}{|l|}{ 貂(Martes flavigula)、黄叟(Mustela sibirica) } \\
\hline 帚尾豪猪(Atherurus macrourus) & 西藏墨脱县 & 活动节律与月光周期关系 & 温立嘉等, 2016 \\
\hline $\begin{array}{l}\text { 岩松鼠(Sciurotamias davidianus)、中华斑羚(Naemorhedus griseus)、狍(Capreolus } \\
\text { pygargus) }\end{array}$ & 北京雾灵山自然保护区 & 日活动节律 & 汤小明等, 2016 \\
\hline $\begin{array}{l}\text { 小泡巨鼠(Leopoldamys edwardsi)、帚尾豪猪(Atherurus macrourus)、赤腹松鼠 } \\
\text { (Callosciurus erythraeus)、北树舄(Tupaia belangeri)、赤鹿(Muntiacus muntjak)、白鹏 } \\
\text { (Lophura nycthemera) }\end{array}$ & 广西弄岗森林动态监测样地 & 日活动节律 & 李生强等, 2016 \\
\hline 北山羊(Capra ibex) & 新疆阿尔泰山东部 & 日活动节律以及季节性变化 & 胡亮等, 2016 \\
\hline 马鹿(Cervus elaphus) & 内蒙古赛罕乌拉国家级自然保护区 & 日活动节律以及季节性变化 & 陈琛等, 2017 \\
\hline 普氏野马(Equus przewalskii) & 新疆卡拉麦里山有蹄类自然保护区 & 日活动节律以及季节性变化 & 吴兵等, 2017 \\
\hline $\begin{array}{l}\text { 岩松鼠(Sciurotamias davidianus)、北花松鼠(Tamias sibiricus)、亚洲狗獾(Meles leucurus)、 } \\
\text { 猪獾(Arctonyx collaris)、豹猫(Prionailurus bengalensis)、貉(Nyctereutes procyonoides)、 } \\
\text { 花面狸(Paguma larvata)、中华斑羚(Naemorhedus griseus)、野猪(Sus scrofa) }\end{array}$ & 北京松山国家级自然保护区 & 日活动节律的季节性变化 & 张源笙等, 2017 \\
\hline 红腹锦鸡(Chrysolophus pictus)、红腹角雉(Tragopan temminckii) & 陕西省佛坪国家级自然保护区 & 日活动节律以及季节性变化 & 刘小斌等, 2017 \\
\hline 白鸠(Lophura nycthemera) & 浙江古田山国家级自然保护区 & 日活动节律 & 余建平等, 2017 \\
\hline 白鹏(Lophura nycthemera) & 浙江风阳山一百山祖国家级自然保护区 & 日活动节律 & 吴友贵等, 2017 \\
\hline 红腹角雉(Tragopan temminckii) & 湖北神农架国家级自然保护区 & 人为干扰与活动节律 & 李佳等, 2017 \\
\hline 雪豹(Panthera uncia) & 四川卧龙国家级自然保护区 & 日活动节律 & 唐卓等, 2017a \\
\hline 绿尾虹雉(Lophophorus Ihuysii) & 四川卧龙国家级自然保护区 & 日活动节律 & 唐卓等, 2017b \\
\hline 蒙古野驴(Equus hemionus) & 新疆卡拉麦里山有蹄类自然保护区 & 日活动节律以及季节性变化 & 吴洪潘等, 2014 \\
\hline 绿尾虹雉(Lophophorus Ihuysii) & 四川小寨子沟国家级自然保护区 & 日活动节律以及季节性变化 & 陈俊橙等, 2018 \\
\hline
\end{tabular}

\section{参考文献}

Bu H, Wang F, McShea WJ, Lu Z, Wang D, Li S (2016) Spatial co-occurrence and activity patterns of mesocarnivores in the temperate forests of southwest China. PLoS ONE, 11, e0164271. 
陈立军, 束祖飞, 肖治术. 应用红外相机数据研究动物活动节律一一以东车八岭保护区鸡形目鸟类为例. 生物多样性, 2019, 27 (3): $266-272$.

http://www.biodiversity-science.net/CN/10.17520/biods.2018178

Chen JC, He F, Peng B, Yu X, Wu YJ, Ran JH (2018) Daily activity pattern of Lophophorus lhuysii during spring and summer in Xiaozhaizigou National Nature Reserve, Sichuan. Sichuan Journal of Zoology, 37,

241-250. (in Chinese with English abstract) [陈俊橙, 贺飞, 彭波, 余翔, 吴永杰，再江洪 (2018) 四川小寨子沟国家级自然保护区绿尾虹雉的日活动行为特征. 四川动物, 37, 241-250.]

Chen C, Hu L, Chen ZJ, Jiang XL, Wu LJ, Wang XL, Bao WD (2017) Variations in seasonal activity pattern of red deer in southern part of Daxing’an Ling Mountains, northeastern China. Journal of Beijing Forestry University, 39(4), 55-62. (in Chinese with English abstract) [陈琛, 胡否, 陈照娟, 姜秀丽, 乌力吉, 王晓玲, 鲍伟东 (2017) 大兴安岭南段马鹿日活动节律的季节变化研究. 北京林业大学学报, 39(4), $55-62.1$

Chen MT, Tewes ME, Pei KJ, Grassman LI (2009) Activity patterns and habitat use of sympatric small carnivores in southern Taiwan. Mammalia, 73, 20-26.

Duan LJ (2014) Study on Activity and Habitat Use of Giant Panda and its Sympatric Species in Wanglang Nature Reserve. Master dissertation, Beijing Forestry University, Beijing. (in Chinese with English abstract) [段利娟 (2014) 王朗自然保护区大熊猫及其同域物种活动节律及栖息地利用研究. 硕士学位论文, 北京林业大学, 北京.]

Hu L, Chu HJ, Wang L, Liu YC, Zhang JY, Chen G (2016) Activity pattern of Capra ibex by camera-trapping in the eastern Altai Mountains. Biotechworld, (4), 36-39. (in Chinese) [胡亮, 初红军, 王丽, 刘元

超，张钧泳，陈刚 (2016) 基于红外相机陷阱技术的阿尔泰山东部北山羊(Capra ibex)的活动节律. 生物技术世界, (4), 36-39.]

Huang PL, Xiao WH, Yang HT, Zhou B, Zhao XD, Wu HY, Feng LM, Wang TM (2015) Activity patterns and group behaviors of sika deer (Cervus nippon mantchuricus). Journal of Beijing Normal University

(Natural Science), 51, 498-503. (in Chinese with English abstract) [黄沛琳, 肖文宏, 杨海涛, 周博, 赵小丹, 武红艳, 冯利民, 王天明 (2015) 东北梅花鹿种群活动节律和集群行为研究. 北京师范大 学学报(自然科学版), 51, 498-503.]

Hwang MH, Garshelis DL (2007) Activity patterns of Asiatic black bears (Ursus thibetanus) in the central mountains of Taiwan. Journal of Zoology, 271, 203-209.

Jia XD, Liu XH, Yang XZ, Wu PF, Songer M, Cai Q, He XB, Zhu Y (2014) Seasonal activity patterns of ungulates in Qinling Mountains based on camera-trap data. Biodiversity Science, 22, 737-745. (in Chinese

with English abstract) [贾晓东, 刘雪华, 杨兴中, 武鹏峰, Songer M, 蔡琼, 何祥博, 朱云 (2014) 利用红外相机技术分析秦岭有蹄类动物活动节律的季节性差异. 生物多样性, 22, 737-745.]

Li F, Jiang ZG (2014) Is nocturnal rhythm of Asian badger (Meles leucurus) caused by human activity? A case study in the eastern area of Qinghai Lake. Biodiversity Science, 22, 758-763. (in Chinese with

English abstract) [李峰, 蒋志刚 (2014) 狗獾夜间活动节律是受人类活动影响而形成的吗? 基于青海湖地区的研究实例. 生物多样性, 22, 758-763.] 
陈立军, 束祖飞, 肖治术. 应用红外相机数据研究动物活动节律一一以东车八岭保护区鸡形目鸟类为例. 生物多样性, 2019, 27 (3): $266-272$.

http://www.biodiversity-science.net/CN/10.17520/biods.2018178

Li J, Liu F, Li DQ, Xu HQ, Jiang J (2017) Daily activity rhythm of temminick’ s tragopan (Trgopan temminckii) based on infrared camera monitoring. Scientia Silvae Sinicae, 53, 170-176. [李佳, 刘芳, 李迪强,

徐海青, 蒋军 (2017) 基于红外相机监测分析的红腹角雉日活动节律. 林业科学, 53, 170-176.]

Li MF, Li S, Wang DH, McShea WJ, Guan TP, Chen LM (2011) The daily activity patterns of takin Budorcas taxicolor in winter and spring at Tangjiahe Nature Reserve, Sichuan Province. Sichuan Journal of Zoology, 30, 850-855. (in Chinese with English abstract) [李明富, 李晟, 王大军, McShea WJ, 官天培, 谌利民 (2011) 四川唐家河自然保护区扭角羚冬春季日活动模式研究. 四川动物, 30, 850-855.]

Li Q (2015) Population Density and Activity Rhythms of Amur Tiger’s Main Prey in Wangqing Nature Reserve, Jilin Province, China. Master dissertation, Northeast Forestry University, Haerbin. (in Chinese with English abstract) [李琦 (2015) 吉林汪清自然保护区东北虎主要猎物种群密度及活动节律的研究. 硕士学位论文, 东北林业大学, 哈尔滨.]

Li S, McShea WJ, Wang DJ, Shao LK, Shi XG (2010) The use of infrared-triggered cameras for surveying phasianids in Sichuan Province, China. Ibis, 152, 299-309.

Li SQ, Wang GH, Shi ZP, Li XK, Xiao ZS, Zhou QH (2016) Infrared camera traps for monitoring mammal and bird diversity and activity pattern in limestone habitats. Acta Theriologica Sinica, 36, 272-281. (in

Chinese with English abstract) [李生强, 汪国海, 施泽攀, 李先琨, 肖治术, 周岐海 (2016) 红外相机技术监测喀斯特生境兽类和鸟类多样性及活动节律. 兽类学报, 36, 272-281.]

Liu DZ, Huang XW, Chu HJ, Liu YC, Zhang F, Chen G, Qi YJ (2015) Activity rhythms of Sino-Mongolia beaver (Caster fiber birulai) measured with infrared camera traps in Xinjiang, China. Arid Zone Research, 32, 205-211. (in Chinese with English abstract) [刘冬志, 黄效文, 初红军, 刘元超, 张帆, 陈刚, 戚英杰 (2015) 基于红外相机陷降技术的蒙新河狸(Caster fiber birulai)活动节律. 干旱区研究, 32, 205-211.]

Liu XB, Wei W, Zheng XG, Zhao KH, He SW, Zhou WL (2017) Activity rhythms of golden pheasant (Chrysolophus pictus) and satyr tragopan (Tragopan temmminckii) revealed by infrared-triggered cameras.

Chinese Journal of Zoology, 52, 194-202. (in Chinese with English abstract) [刘小斌, 韦伟, 郑䈗光, 赵凯辉, 何少文, 周文良 (2017) 红腹锦鸡和红腹角雉活动节律一一基于红外相机监测数据. 动物学 杂志, 52, 194-202.]

McCullough DR, Pei KJ, Wang Y (2000) Home range, activity patterns, and habitat relations of Reeves’ muntjacs in Taiwan. The Journal of Wildlife Management, 64, 430-441.

Pei KJ (1995) Activity rhythm of the spinous country rat (Niviventer coxingi) in Taiwan. Zoological Studies, 34, 55-58.

Pei KJ (1998) An evaluation of using auto-trigger cameras to record activity patterns of wild animals. Taiwan Journal of Forestry Science, 13, 317-324. (in Chinese with English abstract) [裴家骐 (1998) 利用自动 
陈立军, 束祖飞, 肖治术. 应用红外相机数据研究动物活动节律一一以东车八岭保护区鸡形目鸟类为例. 生物多样性, 2019, 27 (3): $266-272$. http://www.biodiversity-science.net/CN/10.17520/biods.2018178

\section{照相设备记录野生动物活动模式之评估. 台湾林业科学, 13, 317-324.]}

Tang XM, Zhang DH, Ma ZH, Wu TL, Zhang YS, Bao WD (2016) Camera trapping survey on ground-dwelling birds and mammals of spring and winter in Beijing Wulingshan Nature Reserve. Chinese Journal of Zoology, 51, 751-760. (in Chinese with English abstract) [汤小明, 张德怀, 马志红, 吴同路, 张源笙, 鲍伟东 (2016) 北京雾灵山自然保护区冬春季地面活动鸟兽红外相机初步调查. 动物学杂志, $51,751-760$.

Tang Z, Yang J, Liu XH, Wang PY, Li ZY (2017a) Research on snow leopards (Panthera uncia) using camera-trapping in Wolong National Nature Reserve, China. Biodiversity Science, 25, 62-70. (in Chinese with English abstract) [唐卓，杨建，刘雪华，王鹏彦，李周园 (2017a) 基于红外相机技术对四川卧龙国家级自然保护区雪豹(Panthera uncia)的研究. 生物多样性, 25, 62-70.]

Tang Z, Yang J, Liu XH, Wang PY, Li ZY, Liu CS (2017b) Activity pattern of Lophophorus lhuysii by camera-trapping in Wolong National Nature Reserve, China. Sichuan Journal of Zoology, 36, 582-587. (in Chinese with English abstract) [唐卓, 杨建, 刘雪华, 王鹏彦, 李周园, Liu CS (2017b) 利用红外相机研究卧龙国家级自然保护区绿尾虹雉的活动规律. 四川动物, 36, 582-587.]

Wang CP, Liu XH, Wu PF, Cai Q, Shao XM, Zhu Y, Songer M (2015) Research on behavior and abundance of wild boar (Sus scrofa) via infrared camera in Guanyinshan Nature Reserve in Qinling Mountains, China. Acta Theriologica Sinica, 35, 147-156. (in Chinese with English abstract) [王长平, 刘雪华, 武鹏峰, 蔡琼, 郡小明, 朱云, Songer M (2015) 应用红外相机技术研究秦岭观音山自然保护区内野猪 的行为和丰富度. 兽类学报, 35, 147-156.]

Wang GH, Shi ZP, Li SQ, Zhou QH (2015) Activity pattern of Muntiacus muntjak revealed with infrared camera. Journal of Guangxi Normal University (Natural Science), 33(3), 117-122. (in Chinese with English abstract) [汪国海，施泽攀，李生强，周岐海 (2015) 基于红外相机技术的赤鹿活动模式分析. 广西师范大学学报(自然科学版), 33(3), 117-122.]

Wu YG, Ye ZL, Wu YS, Xu DM, Zhou RF (2017) Activity patterns of Lophura nycthemera based on camera trap data. Sichuan Journal of Zoology, 36, 25-29. (in Chinese with English abstract) [吴友贵, 叶珍 林, 吴义松, 许大明, 周荣飞 (2017) 基于红外相机技术的野生白㸚活动规律. 四川动物, 36, 25-29.]

Wang Y, Chu HJ, Han LL, Ge Y, Tao YS, Bu L (2014) Activity of Canis lupus in the Karamori Mountain Ungulate Nature Reserve based on trap technique of infrared camera. Arid Zone Research, 31, 771-778. (in Chinese with English abstract) [王波, 初红军, 韩丽丽, 葛炎, 陶永善, 布兰 (2014) 基于红外相机陷阱技术的卡拉麦里山有蹄类自然保护区狼(Canis lupus)的活动节律. 干旱区研究, 31, 771-778.] 
陈立军, 束祖飞, 肖治术. 应用红外相机数据研究动物活动节律一一以东车八岭保护区鸡形目鸟类为例. 生物多样性, 2019, 27 (3): $266-272$.

http://www.biodiversity-science.net/CN/10.17520/biods.2018178

Wen LJ, Guo YM, Huang J, Song Y (2016) The activity rhythm of the Asiatic brush-tailed porcupine Atherurus macrourus and its correlation with the phases of the moon. Chinese Journal of Zoology, 51, 347-352.

(in Chinese with English abstract) [温立嘉, 郭玉民, 黄建, 宋阳 (2016) 帚尾豪猪活动节律及其与月光周期的相关性. 动物学杂志, 51, 347-352.]

Wu B, Chu WW, Wu HP, Ren SB, He L, Ge Y, Bu L, Chu HJ (2017) Activity rhythms of reintroducing Przewalski’s horse (Equus przewalskii) at watering holes by camera traps. Chinese Journal of Zoology, 52,

545-554. (in Chinese with English abstract) [吴兵, 初雯雯, 吴洪潘, 任松柏, 贺雷, 葛炎, 布兰, 初红军 (2017) 卡拉麦里山有蹄类自然保护区水源地野放普氏野马的活动节律: 基于红外相机监测数据.

动物学杂志, 52, 545-554.]

Wu HP, Chu HJ, Wang Y, Ma JW, Ge Y, Bu L (2014) Monitoring activity rhythms of Equus hemionus at watering holes by camera traps in Mount Kalamaili Ungulate Nature Reserve, Xinjiang. Biodiversity

Science, 22, 752-757. (in Chinese with English abstract) [吴洪潘, 初红军, 王洲, 马建伟, 葛炎, 布兰 (2014) 卡拉麦里山有蹄类自然保护区水源地蒙古野驴的活动节律: 基于红外相机监测数据. 生 物多样性, 22, 752-757.]

Xue YD, Sun ZC, Wu P, Zhang YG, Li DQ (2015) Time budgets and diurnal activity rhythms of re-introduced wild bactrian camels in semi-free environment during early winter. Scientia Silvae Sinicae, 51,

169-174. (in Chinese with English abstract) [薛亚东, 孙志成, 吴鹏, 张于光, 李迪强 (2015) 散养条件下野生双峰驼初冬活动时间分配及节律. 林业科学, 51, 169-174.]

Yu JP, Qian HY, Chen XN, Li S, Shen XL (2017) Daily activity pattern of silver pheasant (Lophura nycthemera) using camera-traps. Chinese Journal of Zoology, 52, 937-944. (in Chinese with English abstract) [余

建平, 钱海源, 陈小南, 李晟, 申小莉 (2017) 基于红外相机技术的白鹏日活动节律研究. 动物学杂志, 52, 937-944.]

Zhang SS, Bao YX, Wang YN, Fang PF, Ye B (2012) Activity rhythms of black muntjac (Muntiacus crinifron) revealed with infrared camera. Acta Theriologica Sinica, 32, 368-372. (in Chinese with English

abstract) [章书声，鲍毅新，王艳妮，方平福，叶涁 (2012) 基于红外相机技术的黑鹿活动节律. 兽类学报, 32, 368-372.]

Zhang YS, Jiang J, Jiang WJ, Wang D, Fan YQ, Tang XM, Bao WD (2017) Activity patterns of mammals in Beijing Songshan National Nature Reserve. Sichuan Journal of Zoology, 36, 460-467. (in Chinese with

English abstract) [张源笙，蒋健，蒋万杰，王丹，范雅倩，汤小明，鲍伟东 (2017) 北京松山国家级自然保护区兽类活动节律初步研究. 四川动物, 36, 460-467. ]

Zhao YZ, Wang ZC, Xu JL, Luo X, An LD (2013) Activity rhythm and behavioral time budgets of wild Reeves’s pheasant (Syrmaticus reevesii) using infrared camera. Acta Ecologica Sinica, 33, 6021-6027. (in

Chinese with English abstract) [赵玉泽, 王志臣, 徐基良, 罗旭, 安丽丹 (2013) 利用红外照相技术分析野生白冠长尾雉活动节律及时间分配. 生态学报, 33, 6021-6027.] 